\title{
Numerical analysis of a serial connection of two staged SOFC stacks in a CHP system fed by methane using Aspen TECH
}

\author{
Paulina Pianko-Oprych*, Mateusz Palus \\ West Pomeranian University of Technology, Szczecin, Faculty of Chemical Technology and Engineering, Institute of \\ Chemical Engineering and Environmental Protection Processes, Piastów Ave. 42, 71-065 Szczecin, Poland \\ *Corresponding author: e-mail: paulina.pianko@zut.edu.pl
}

\begin{abstract}
The objective of the study was to develop a steady-state system model in Aspen TECH using user-defined subroutines to predict the SOFC electrochemical performance. In order to achieve high overall fuel utilization and thus high electrical efficiency, a concept of Combined Heat and Power system with two-stage SOFC stacks of different number of cells was analyzed. The concept of two-stage SOFC stacks based system was developed in the framework of the FP7 EU-funded project STAGE-SOFC. The model was validated against data gathered during the operation of the proof-of-concept showing good agreement with the comparative simulation data. Following model validation, further simulations were performed for different values of fuel utilization to analyze its influence on system electrical performance. Simulation results showed that the concept of two-stage SOFC stacks configuration was viable and reliable. The model can be useful for development the optimal control strategy for system under safe conditions.
\end{abstract}

Keywords: Solid Oxide Fuel Cell stacks, Combined Heat and Power system, Balance of Plant, BoP, modelling, methane, Catalytic Partial Oxidation, CPOx, reformer, steam reformer, part and full load, steady state, dynamic model.

\section{INTRODUCTION}

In recent years several alternative designs of Combined Heat and Power, CHP, system based on Solid Oxide Fuel Cells, SOFCs, were investigated numerically ${ }^{1}$. Research studies included single pass SOFC stack systems and configurations with recirculation. As one of the first Araki et al. $^{2}$ analysed a power generation system consisting of two stages externally reformed SOFCs with serial connection of low and high temperature SOFCs. Authors showed that the power generation efficiency of the two-stage SOFCs was $50.3 \%$ and the total efficiency of power generation with gas turbine was $56.1 \%$ under standard operating conditions of SOFC temperature $750^{\circ} \mathrm{C}$, current density $0.3 \mathrm{~A} / \mathrm{cm}^{2}$ and cell pressure $1 \mathrm{MPa}$.

Two types of combined cycles of a two-stage combination of Intermediate Temperature IT-SOFC and High Temperature HT-SOFC with two stages of IT-SOFC were also evaluated using numerical models in Aspen Plus $^{\mathrm{TM}}$ by Musa and Paepe ${ }^{3}$. In both combined cycles, the anode flows of the first and second stage fuel cell stacks were connected in parallel, while the cathode flow was connected serially. The simulation results showed that a single-stage HT-SOFC and IT-SOFC had an efficiency of $57.6 \%$ and $62.3 \%$, respectively. A combined cycle of two-stage IT-SOFC gave $65.5 \%$ under standard operational conditions of pressure 6 bar and of temperature $750^{\circ} \mathrm{C}$ and $850^{\circ} \mathrm{C}$ for IT-SOFC and HT-SOFC respectively. In addition, it was noted that the heat exchanger between the two fuel cells in the cathode stream can be omitted as the operating temperature in the IT-SOFC was lower.

Alternative solution of a design was proposed by $\mathrm{Mu}-$ shtaq et al. ${ }^{4}$ with a flat tubular segmented in series, SIS, SOFC sub module composed of a 5 unit cell. Electrochemical performance analysis was conducted between 600 and $800^{\circ} \mathrm{C}$ using $300 \mathrm{CC} / \mathrm{min} 3$ vol. \% humidified hydrogen fuel and $1500 \mathrm{CC} / \mathrm{min}$ air as oxidant. It was showed that application of an LSCo layer enhanced the performance from 401 to $522 \mathrm{~mW} / \mathrm{cm}^{2}$ at $750^{\circ} \mathrm{C}$. The average open circuit voltage, OCV, of the flat tubular SIS-SOFC 5-cell sub module was equal to 5.0-5.2 V, which was the value of $0.25-0.50 \mathrm{~V}$ less than the theoretical OCV. The lower value of OCV was explained due to the leakage of the reacting gases through the interconnector layer and ceramic sealant. The design resulted in higher power density per unit volume and improved the overall tubular SOFC by increasing the thickness of the cathode and adaptation of the current collector. An et al. ${ }^{5}$ tested a flattened tubular segmented in series, SIS, SOFC stack as well. The aim was to improve an active area per cell and the fuel cell efficiency. Authors ${ }^{5}$ found that when the unit cell was laminated on all sides of SIS SOFC on a porous ceramic support, the active area per cell increases 2.6 times. The output increases by 2.5 times, while the polarization resistance decreases by $35 \%$.

On the other hand, Ding and $\mathrm{Liu}^{6}$ presented a cone shaped tubular segmented in series two cell SOFC stack. The cone shaped tubular anode substrates were fabricated by slip casting technique and the Yttria Stabilized Zirconia, YSZ, electrolyte films were deposited onto the anode by dip coating method. The single cell, NiO-YSZ/YSZ/LSM-YSZ provides a maximum power density of $1.78 \mathrm{~W} / \mathrm{cm}^{2}$ at $800^{\circ} \mathrm{C}$ using moist hydrogen as fuel and ambient air as oxidant. The continuation of the study ${ }^{6}$ is the work ${ }^{7}$, where a cone shaped Solid Oxide Fuel Cell stack was assembled by connecting 11 single cells in series. The 11 cell stack provides a maximum output of about $8 \mathrm{~W}$ at $800^{\circ} \mathrm{C}$ and $6 \mathrm{~W}$ at $700^{\circ} \mathrm{C}$, when operated with humidified methane fuel ${ }^{7}$. The SIS SOFC CHP system for residential house using 36 cell stacks was examined also by Fujita et al. ${ }^{8}$. A power density of $0.186 \mathrm{~W} / \mathrm{cm}^{2}$ was obtained at a current density of 0.24 $\mathrm{A} / \mathrm{cm}^{2}$ at $825^{\circ} \mathrm{C}$. However, authors ${ }^{8}$ mentioned that it was difficult for SIS SOFCs to remain at their operating temperature with a high degree of fuel utilization during partial load operation. Despite this the SIS SOFC CHP 
system achieved an overall LHV efficiency of $75 \%$ and its successful operation was demonstrated for over $4000 \mathrm{~h}$.

Recently, a new conceptual micro-CHP with two serially connected integrated stack modules with 30 cells in the SOFC stack was analysed numerically and experimentally by Kupecki et al. ${ }^{9}$. It was shown that maximum efficiency of the stacks was achieved in the range of parameters where the first stack operated at a moderate current density, while the second stack at very low electrical load. The highest electrical efficiency of $46.4 \%$ was achieved at current densities 0.275 and $0.07 \mathrm{~A} / \mathrm{cm}^{2}$ at the system level simulation performed using Aspen HYSYS 8.0. An increased the output power of the system based on the connection of two stacks in series in the manner presented in the study ${ }^{9}$ resulted from the use of lean fuel from the first stack in the second one. A further advantage of the use of two fuel cell stacks within one power unit was spotted in operational flexibility unavailable to systems with a recirculation loop.

The latest multi-stack SOFC prototype assembly for combined heat and power was proposed by Anyenya et al. ${ }^{\mathbf{1 0}}$. The prototype consists of three $1.5 \mathrm{~kW}_{\mathrm{e}}$ SOFC stack and combustor assemblies packaged. A steady-state system model was developed in Aspen Plus ${ }^{\mathrm{TM}}$ using user defined subroutines to predict the stack electrochemical performance of the stacks and heat loss from the module at different operating conditions under a hydrogen fuel blend. Simulation results revealed that the electric current can be used to increase the module electric power and heat flux while keeping the combined heat and power efficiency of the system nearly constant. In addition, the fuel utilization can be used to increase system efficiency and to decrease the heat flux to the geology during turn-down conditions. Finally, the stack temperature can be controlled by varying the flow of excess cooling air. However, increased air flow rates resulted in high compressor electric power demands.

The few trials available in literature investigating the serial connection of two or more staged SOFC stacks in the CHP systems revealed that higher efficiencies and lower capital costs can be achieved. However, experi- mental investigation of the complex hybrid SOFC system is extremely difficult due to high cost of the apparatus. Therefore, the majority of the systems were analysed numerically. Numerical analysis allowed to study the overall system layout as well as to consider different type of reforming arrangement and fed streams. As a result, much more detailed design of the CHP systems that can be economically feasible and reliable were reported in the numerical studies. In addition, to achieve high efficiency during the part load operation of the CHP system a special control strategy and management have to be implemented. And again, experimental study of the CHP system in part load conditions is much more difficult to manage than software simulation due to the coupling between staged SOFC stacks and auxiliary system components. It should be noticed that in numerical investigation hundreds of analyses can be carried out without the risk of fuel cells degradation or damage.

The objective of the study is to develop the steady state model of two-stage SOFC stacks in the CHP system. To investigate the behaviour of the hybrid system, two-dimensional models of two reformers, heat exchanger, two-stage SOFC stacks and burner using Aspen TECH were developed. Each component models of SOFC stacks, reformers, heat exchanger and burner have been verified by comparison with data ${ }^{\mathbf{1 1}, \mathbf{1 2}}$. The present model can be utilized to develop dynamic model, which may be helpful in defining the optimal control strategy of two-stage SOFC stacks in the CHP system during various transient conditions.

\section{Numerical approach}

An Aspen Plus v8.4 simulation model was developed in order to estimate the Combined and Heat Power system with two-stage SOFC stacks performance. The integrated simulation model of the SOFC CHP system shown in Fig. 1 is divided in three major subsystems: a fuel processor section, a fuel cell power system and a heat recovery section. The primary fuel reforming reactor is based on Catalytic Partial Oxidation reforming, $\mathrm{CPO}_{\mathrm{x}}$, while the second one is based on Steam Reforming,

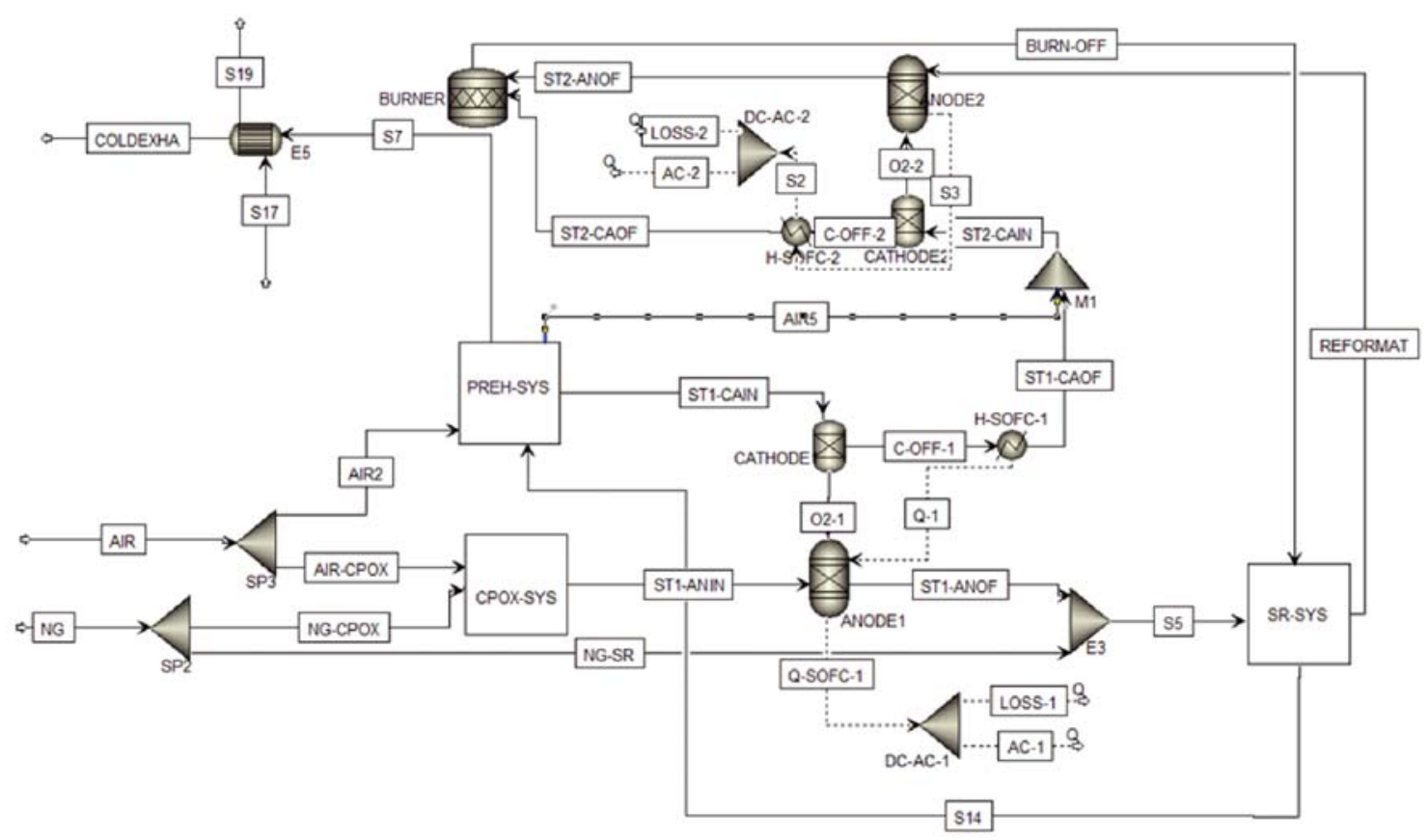

Figure 1. Twostage SOFC stacks in CHP system layout 
SR. The SR reactor is connected to Water Gas Shift, WGS, reaction to further reduce CO contamination to acceptable levels. The second subsystem of the simulation model describes two-stage SOFC stacks containing 90 and 240 fuel cells, respectively. The last section contains several auxiliary heat exchangers and burners that are required to preheat the incoming fuel, air and steam as well as to supply heat to the endothermic SR process.

The main assumptions invoked in this model are as follows:

- Zero-dimensional approach.

- Steady-state condition.

- The fed natural gas "NG" is composed of a mixture of $98.3 \% \mathrm{CH}_{4}, 0.5 \% \mathrm{C}_{2} \mathrm{H}_{6}, 0.3 \% \mathrm{C}_{3} \mathrm{H}_{8}, 0.1 \% \mathrm{C}_{4} \mathrm{H}_{10}, 0.8 \%$ $\mathrm{N}_{2}$. The molar flow rate is equal to $0.018024 \mathrm{~mol} \cdot \mathrm{s}^{-1}$ at the pressure of 1.04 bar.

- The inlet air flow rate "AIR" is equal to $0.3922 \mathrm{~mol} \cdot \mathrm{s}^{-1}$ at the inlet pressure of 1.00 bar and its compression was assumed equal to 1.04 bar. The air compression is carried out using a compressor $\mathrm{C} 1$ and the appropriate air flow "AIR1" is delivered to the separator SP3 at assumed pressure.

- Internal fuel processing: reforming and CO-shift reactions at equilibrium.

- The separator unit operation blocks "SP2" and "SP3" are responsible for delivering appropriate amounts of the fed gas "NG" and "AIR" to the reformer "CPOX" according to the user desired split fraction named the lambda number, $\lambda=0.3092$. The lambda number represents the molar ration of the air to carbon entering the $\mathrm{CPO}_{\mathrm{x}}$ reformer and it was defined by equation (1):

$$
\lambda=\frac{0,21 \cdot \dot{\mathrm{V}}_{\text {air }}}{\left(2 \cdot \mathrm{r}_{\mathrm{CH} 4}+3,5 \cdot \mathrm{r}_{\mathrm{C} 2 \mathrm{H} 6}+5 \cdot \mathrm{r}_{\mathrm{C} 3 \mathrm{H} 8}+6,5 \cdot \mathrm{r}_{\mathrm{C} 4 \mathrm{H} 10}\right) \cdot \dot{\mathrm{V}}_{\mathrm{NG}}}
$$

where: $\dot{\mathrm{V}}_{\text {air }}$ and $\dot{\mathrm{V}}_{\mathrm{NG}}$ were the volume flow rates of the air and natural gas entering the $\mathrm{CPO}_{\mathrm{x}}$ reformer, $\mathrm{r}_{\mathrm{i}}$ is the molar fraction of $i$ - components.

- The volume flow rate of the stream entering to the $\mathrm{CPO}_{\mathrm{x}}$ reformer named as "AIR-CPOX" was calculated using a Calculator-1 block based on the equation (1) and the volume flow rate of the stream "NG-CPOX".

- A sensitivity analyze "S-1" was conducted to evaluate the outlet rate flow "NG-SR" for the separator unit operation block "SP2". The sensitivity specification block was needed to check the value of the ratio $\mathrm{O} / \mathrm{C}$ in the stream "S5" and to estimate the influence of the molar flow rate "NG-SR" on it.

- The outlet stream from the $\mathrm{CPO}_{\mathrm{x}}$ reformer "ST1-ANIN" was supplied to the anode side "ANODE1" of the first SOFC stack. The exhaust gas from the first SOFC stack "ST1-ANOF" was mixed with the fresh stream of natural gas "NG-SR" and then directed to SR reactors. Finally, the fuel "REFORMAT" was fed into the anode side "ANODE2" of the second SOFC stack. Exhaust gas from the second SOFC stack "ST2-ANOF" was burnt with the cathode off gas "ST2-CAOF" in the burner. The outlet stream from the burner "BURN-OFF" was directed to the steam reforming sub-system.

- Material balance:

$\sum_{i=1}^{\text {inputs }} \dot{n}_{i}=\sum_{k=1}^{\text {ouputs }} \dot{n}_{k}$ where: $\dot{n}_{i}$ and $\dot{n}_{k}$ are molar flow of component entering and leaving the block, respectively.

- Energy balance:

$\sum_{i=1}^{\text {inputs }} \dot{n}_{i} \cdot h_{i}=\sum_{k=1}^{\text {outputs }} \dot{n}_{k} \cdot h_{k}$

where: $h_{i}$ and $h_{k}$ are molar enthalpy of component entering and leaving the block, respectively.

Gross electrical efficiency is determined by the equation (4):

$\eta_{\text {el,gross }}=\frac{P_{\text {el }, A C}}{\dot{V}_{\text {fuel }} \cdot \mathrm{LHV} \text { fuel }}$

where: $P_{e l, A C}$ is summarized AC electrical power from both stacks, $\dot{V}_{\text {fuel }}$ is volume flow rate of fuel and $L H V_{\text {fuel }}$ is the lower heating value of fuel (LHV) calculated according to the equation (5):

$L H V_{\text {fuel }}=\sum_{i} y_{i} \cdot L H V_{i}$

where: $y_{i}$ is volume fraction of combustible $i$ - component, $L H V_{i}$ is lower heating value of combustible $i$ - component.

The construction of each of the components is described below.

\section{Reformer $\mathrm{CPO}_{\mathrm{x}}$}

The natural gas before entering the first SOFC stack was reformed in the $\mathrm{CPO}_{\mathrm{x}}$ reformer named "CPOX". In the Aspen Plus the $\mathrm{CPO}_{\mathrm{x}}$ reformer was defined by the equilibrium reactor module $R G i b b s$ working at the pressure of 1.04 [bar]. Adiabatic and steady state operation was assumed. The following chemical reactions were specified in the $\mathrm{CPO}_{\mathrm{x}}$ reformer block:

$$
\begin{aligned}
& \mathrm{CH}_{4}+0.5 \mathrm{O}_{2} \rightarrow 2 \mathrm{H}_{2}+\mathrm{CO} \\
& \mathrm{CH}_{4}+2 \mathrm{O}_{2} \rightarrow 2 \mathrm{H}_{2} \mathrm{O}+\mathrm{CO}_{2} \\
& 2 \mathrm{H}_{2}+\mathrm{O}_{2} \rightarrow 2 \mathrm{H}_{2} \mathrm{O} \\
& 2 \mathrm{CO}+\mathrm{O}_{2} \rightarrow 2 \mathrm{CO}_{2} \\
& \mathrm{C}_{2} \mathrm{H}_{6}+\mathrm{O}_{2} \rightarrow 3 \mathrm{H}_{2}+2 \mathrm{CO} \\
& \mathrm{C}_{2} \mathrm{H}_{6}+3.5 \mathrm{O}_{2} \rightarrow 3 \mathrm{H}_{2} \mathrm{O}+2 \mathrm{CO}_{2} \\
& \mathrm{C}_{3} \mathrm{H}_{8}+1.5 \mathrm{O}_{2} \rightarrow 4 \mathrm{H}_{2}+3 \mathrm{CO} \\
& \mathrm{C}_{3} \mathrm{H}_{8}+5 \mathrm{O}_{2} \rightarrow 4 \mathrm{H}_{2} \mathrm{O}+3 \mathrm{CO}_{2} \\
& \mathrm{C}_{4} \mathrm{H}_{10}+2 \mathrm{O}_{2} \rightarrow 5 \mathrm{H}_{2}+4 \mathrm{CO} \\
& \mathrm{C}_{4} \mathrm{H}_{10}+6.5 \mathrm{O}_{2} \rightarrow 5 \mathrm{H}_{2} \mathrm{O}+4 \mathrm{CO}_{2}
\end{aligned}
$$

The value of the lambda coefficient was calculated using Aspen Plus Calculator C-1 function. The temperature and composition of the stream leaving "CPOX" (stream "ST1-ANIN") was calculated automatically by Aspen Plus. The syngas produced in the $\mathrm{CPO}_{\mathrm{x}}$ reformer and the oxidant "ST1-CAIN" were supplied to the first SOFC stack modelled through the "CATHODE1", "ANODE1" and heater "H-SOFC-1" units, where the electrochemical reaction took place producing the demanded electrical power.

\section{Internal reforming and electrochemical reactions at the anode}

The pre-reformed fuel (stream "ST1-ANIN") was fed to the "ANODE1" block, where the reforming of $\mathrm{CH}_{4}$ to $\mathrm{H}_{2}$ and water gas shift of $\mathrm{CO}$ to $\mathrm{H}_{2}$ occurred. The transfer of ions cannot be modelled in Aspen Plus, therefore the overall reactions (R11) - (R15) instead of the cell half reactions were used in the "ANODE1" block model as follows:

$\mathrm{H}_{2}+0.5 \mathrm{O}_{2} \rightarrow \mathrm{H}_{2} \mathrm{O}$ 
$\mathrm{CH}_{4}+\mathrm{H}_{2} \mathrm{O} \rightarrow 3 \mathrm{H}_{2}+\mathrm{CO}$

$\mathrm{CO}+\mathrm{H}_{2} \mathrm{O} \rightarrow \mathrm{H}_{2}+\mathrm{CO}_{2}$

$\mathrm{H}_{2}+\mathrm{CO}_{2} \rightarrow \mathrm{CO}+\mathrm{H}_{2} \mathrm{O}$

$\mathrm{H}_{2} \mathrm{O} \rightarrow \mathrm{H}_{2}+0.5 \mathrm{O}_{2}$

The „ANODE1" block was characterized by the equilibrium reactor module RGibbs. The stoichiometry of the electrochemical reactions was based on the reactions (R11) - (R15). A pressure drop was defined and equal to 0.01 bar. The outlet temperature of the exhaust gas "ST1-ANOF" was calculated by using an Aspen Plus Design-Spec DS-1 function. The Design-Spec DS-1 function based on specified value of the electrical power "WELECTRIC" and the total of heat losses. The application of the block Calculator C-2 was also required due to the need of specification the amount of the oxygen from air stream transferred from the cathode to the anode assuming the fuel utilization equal to $\mathrm{FU}=0.75$. In addition, two functions transfer $T-1$ and $T-2$ were used to maintain the operating cathode temperature to the value of the cathode inlet stream temperature "ST1-CAIN" as well as to maintain the outlet temperature values from anode "ST1-ANOF" and cathode "ST1-CAOF". A pressure drop was specified for each side of the SOFC and based on the values obtained from the project partner. For the anode, it was assumed of 0.01 bar, while for the cathode 0.005 bar, respectively. The power produced by the first SOFC stack "ISM1" was calculated by Aspen Plus and it was estimated as $2473 \mathrm{~W}$. The power term was represented as the heat stream "Q-SOFC-1". The stream "Q-SOFC-1" in watts $\mathrm{W}$ was directed to the $\mathrm{DC} / \mathrm{AC}$ converter to converts from DC power using the inverter efficiency of $95 \%$. The outlet stream "LOSS-1" represents $5 \%$ of the loss of the converter, while the stream "AC-1" represents the electrical AC power in watts marked by a variable "P_el_AC".

\section{Air stream delivery to the cathode side in the second SOFC stack}

The stream coming out from the cathode "ST1-CAOF" block was directed to the Mixer "M1", where it was connected with the fresh air stream "AIR3". A mixed stream "ST2-CAIN" was supplied to the cathode side in the second SOFC stack "ISM2". The "ISM2" model was built based on the SOFC model for the first stack "ISM1". In this case, the SOFC model for "ISM2" contained as well three model blocks: anode named "ANODE2", cathode - "CATHODE2" and a heater module named "H-SOFC-2". The "CATHODE" was modelled as an oxygen separator using Separator block. In order to ensure correct calculation of the "ISM2" stack function additional design specification, transfer and calculator functions were set to maintain the appropriate operating conditions. For the second SOFC stack the following values of the pressure drop for the anode and cathode were assumed: 0.005 and 0.02 [bar], respectively.

\section{Burner}

The streams coming out from the second SOFC stack "ISM2" block, streams "ST2-ANOF" and "ST2-CAOF" contained mainly steam along with some unburned $\mathrm{H}_{2}$ and CO. Therefore, the depleted fuel was sent to the
"BURNER" fulfilling the role of the combustor. The process of combustion was simulated using the RStoic reactor that worked under the pressure of 1.01 bar and adiabatic condition due to project partner suggestion (heat duty was equal to $0 \mathrm{~W}$ ). Two reactions for the remaining $\mathrm{H}_{2}$ and $\mathrm{CO}$ in the depleted fuel with oxygen have been considered in the burner block:

$\mathrm{H}_{2}+0.5 \mathrm{O}_{2} \rightarrow \mathrm{H}_{2} \mathrm{O}$

$\mathrm{CO}+0.5 \mathrm{O}_{2} \rightarrow \mathrm{CO}_{2}$

The outlet stream named „BURN-OFF” was directed to the steam reforming sub-system.

\section{Steam reforming}

The value of the $\mathrm{O} / \mathrm{C}$ coefficient was calculated to meet in SR subsystem the desired oxygen/carbon, $\mathrm{O} / \mathrm{C}$ ratio value using Aspen Plus Calculator C-4 and Design-Specs DS-1 functions. Too low $\mathrm{O} / \mathrm{C}$ ratio inflicts soot formation on the reforming catalyst. Therefore the desired $\mathrm{O} / \mathrm{C}$ ratio value was equal to 1.60 . The high temperature stream "BURN-OFF" exiting the burner chamber exchanged heat within the steam reforming sub-system. This heat exchange was simulated in the Aspen Plus using a cascade of the RGibbs reactors and heat exchanger modules. The use of the cascade solved problems with a high degree of the air consumption in the second SOFC stack as well as allowed to reduce the SOFC temperature and a risk of catalyst damage. In addition, it also solved the need for heat for endothermic steam reforming reactions (R18) - (R21). In the steam reforming reactors modelled using the $R G i b b s$ module the following reactions (R18) - (R22) were considered: $\mathrm{CH}_{4}+\mathrm{H}_{2} \mathrm{O} \rightarrow 3 \mathrm{H}_{2}+\mathrm{CO}$

$\mathrm{C}_{2} \mathrm{H}_{6}+2 \mathrm{H}_{2} \mathrm{O} \rightarrow 5 \mathrm{H}_{2}+2 \mathrm{CO}$

$\mathrm{C}_{3} \mathrm{H}_{8}+3 \mathrm{H}_{2} \mathrm{O} \rightarrow 7 \mathrm{H}_{2}+3 \mathrm{CO}$

$\mathrm{C}_{4} \mathrm{H}_{10}+4 \mathrm{H}_{2} \mathrm{O} \rightarrow 9 \mathrm{H}_{2}+4 \mathrm{CO}$

Water - Gas Shift, WGS

$\mathrm{CO}+\mathrm{H}_{2} \mathrm{O} \rightarrow \mathrm{CO}_{2}+\mathrm{H}_{2}$ In the outlet stream from the first stack "ISM1" can also be present small amount of $\mathrm{CO}_{2}$. Thus, the additional reaction has been considered in the simulation within the steam reforming sub-system:

Dry Reformation

$\mathrm{CO}_{2}+\mathrm{CH}_{4} \rightarrow 2 \mathrm{H}_{2}+2 \mathrm{CO}$

\section{Basic models}

The complete steady-state model of the serial connected two-stage SOFC stacks required specification block that varies the fuel "NG" flow in the Splitter "SP2" to meet the desired $\mathrm{O} / \mathrm{C}_{\mathrm{SR}}$ ratio equal to 1.60 , which allow to avoid coke formation [11]. The Calculator $C-4$ specification block was automatically adjusted the split fraction $\mathrm{O} / \mathrm{C}_{\mathrm{SR}}$ depending on the desired composition of the stream S5. The $\mathrm{O} / \mathrm{C}_{\mathrm{SR}}$ ratio required was calculated from the equation (6):

$$
\mathrm{O} / \mathrm{C}_{\mathrm{SR}}=\frac{2 \cdot \dot{\mathrm{n}}_{\mathrm{CO}_{2}}+\dot{\mathrm{n}}_{\mathrm{CO}}+\dot{\mathrm{n}}_{\mathrm{H}_{2} \mathrm{O}}}{\dot{\mathrm{n}}_{\mathrm{CO}}+\dot{\mathrm{n}}_{\mathrm{CO}_{2}}+\dot{\mathrm{n}}_{\mathrm{CH}_{4}}+2 \cdot \dot{\mathrm{n}}_{\mathrm{C}_{2} \mathrm{H}_{6}}+3 \cdot \dot{\mathrm{n}}_{\mathrm{C}_{3} \mathrm{H}_{8}}+4 \cdot \dot{\mathrm{n}}_{\mathrm{C}_{4} \mathrm{H}_{10}}}
$$

A second design specification block Design-Spec DS-1 was set to maintain the desired $\mathrm{O} / \mathrm{C}_{\mathrm{SR}}$ ratio by manipulating the split fraction of the Splitter "SP2". 
To calculate the desired DC power two Aspen Plus Calculator block were used. The Calculator $C-5$ estimated the voltage-current parameters for the first 90-cells SOFC stack, while the Calculator $C-6$ was applied for the second 240-cells SOFC stack. The DC-AC power inverter efficiency was assumed to $95 \%$ for both stacks. The system operated at fixed stacks temperature of 800 , 830 and $860^{\circ} \mathrm{C}$ as well as fixed fuel utilization factor of $75 \%$. The fuel utilization factor can be defined from the equation (7):

$F U=\frac{\dot{n}_{H_{2, \text { consumed }}}}{\dot{n}_{H_{2, \text { equivalent }}}}$

where: $\mathrm{H}_{2, \mathrm{eq}}$ was the known equivalent $\mathrm{H}_{2}$ flow rate, thus using the known fuel utilization factor, $\mathrm{FU}$, the amount of $\mathrm{H}_{2}$ consumed, $\mathrm{H}_{2 \text {,consumed }}$, in the anode stack can be obtained.

$\dot{\mathrm{n}}_{\mathrm{H}_{2, \text { consumed }}}=\dot{\mathrm{n}}_{\mathrm{H}_{2, \text { equivalent }}}-\dot{\mathrm{n}}_{\mathrm{H}_{2, \text { depleted }}}$

$\dot{\mathrm{n}}_{\mathrm{H}_{2, \text { equivalent }}}=\dot{\mathrm{n}}_{\mathrm{H}_{2, \text { anode, inlet }}}+1 \cdot \dot{\mathrm{n}}_{\mathrm{CO}_{\text {anode, inlet }}}+4 \cdot \dot{\mathrm{n}}_{\mathrm{CH}_{4, \text { anode }, \text { inlet }}}$

$+7 \cdot \dot{\mathrm{n}}_{\mathrm{C}_{2} \mathrm{H}_{6, \text { anode, inlet }}}+$

$+10 \cdot \dot{\mathrm{n}}_{\mathrm{C}_{3} \mathrm{H}_{8, \text { anode, inlet }}}+13 \cdot \dot{\mathrm{n}}_{\mathrm{C}_{4} \mathrm{H}_{10 \text {,anode, inlet }}}$

$\dot{\mathrm{n}}_{\mathrm{H}_{2, \text { depleted }}}=\dot{\mathrm{n}}_{\mathrm{H}_{2, \text { anode, outlet }}}+1 \cdot \dot{\mathrm{n}}_{\mathrm{CO}_{\text {anode, outlet }}}+4 \cdot \dot{\mathrm{n}}_{\mathrm{CH}_{4, \text { anode, outlet }}}$

$+7 \cdot \dot{\mathrm{n}}_{\mathrm{C}_{2} \mathrm{H}_{6, \text { anode, outlet }}}+$

$+10 \cdot \dot{\mathrm{n}}_{\mathrm{C}_{3} \mathrm{H}_{8, \text { anode, outlet }}}+13 \cdot \dot{\mathrm{n}}_{\mathrm{C}_{4} \mathrm{H}_{10 \text {,anode, outlet }}}$

\section{Electrochemical modelling}

The basic reactions occurring at the cell electrodes of the SOFC can be described as follows:

Anode: $\mathrm{H}_{2}+\mathrm{O}^{2-} \rightarrow \mathrm{H}_{2} \mathrm{O}+2 \mathrm{e}^{-}$

Cathode: $0.5 \mathrm{O}_{2}+2 \mathrm{e}^{-} \rightarrow \mathrm{O}^{2-}$

Overall reaction: $\mathrm{H}_{2}+0.5 \mathrm{O}_{2} \rightarrow \mathrm{H}_{2} \mathrm{O}$

Two electrons conducted around the external circuit for each water molecule formed. Thus, considering the system was a reversible, without any losses, the electrical work done will be equal to the Gibbs energy release out of the reaction (R26) and can be calculated as (11):

$\mathrm{V}_{\mathrm{N}}=\frac{-\Delta \overline{\mathrm{g}}_{\mathrm{f}}}{2 \cdot \mathrm{F}}$

where: $\mathrm{F}$ is the Faraday constant, $\mathrm{F}=96485\left[\mathrm{Cmol}^{-1}\right]$, $\mathrm{V}_{\mathrm{N}}$ is the Nernst voltage, called as Open Circuit Voltage, OCV. The Gibbs free energy, $\Delta \overline{\mathrm{g}}_{\mathrm{f}}$, changes with temperature, pressure and concentration of the reactants and products. So, the OCV in terms of partial pressures of the gas species can be estimated from equation (12):

$\mathrm{V}_{\mathrm{N}}=\mathrm{E}_{0}+\frac{\mathrm{R} \cdot \mathrm{T}}{2 \cdot \mathrm{F}} \ln \left(\frac{\mathrm{p}_{\mathrm{H}_{2}} \cdot \mathrm{p}_{\mathrm{O}_{2}}^{0.5}}{\mathrm{p}_{\mathrm{H}_{2} \mathrm{O}}}\right)$

where: $\mathrm{E}_{0}$ is the reversible potential $\mathrm{J} \cdot \mathrm{mol}^{-1}$ at standard conditions of 1 bar, 2 represents the number of electrons produced per mole of hydrogen fuel reacted, $\mathrm{T}$ is the average SOFC temperature $\mathrm{K}, \mathrm{R}$ is the molar gas constant, $\mathrm{R}=8.314 \mathrm{~J}^{\mathrm{mol}}{ }^{-1} \mathrm{~K}^{-1}, \mathrm{p}_{\mathrm{i}}$ is the partial pressure of gases i - component bar. The reversible potential, $\mathrm{E}_{0}$, was determined from equation (13) ${ }^{13}$ :

$\mathrm{E}_{0}=\frac{4184 \cdot\left[58.3-\left(0.0113+9.6 \cdot 10^{-7} \cdot \mathrm{T}\right) \cdot \mathrm{T}\right]}{2 \mathrm{~F}}$
The actual voltage was calculated from equation (14):

$\mathrm{V}=\mathrm{V}_{\mathrm{N}}-\mathrm{V}_{\text {Ohm }}-\mathrm{V}_{\text {Act }}-\mathrm{V}_{\text {Conc }}$

where: $\mathrm{V}_{\mathrm{Ohm}}-$ Ohmic voltage loss, $\mathrm{V}_{\mathrm{Act}}-$ activation loss and $\mathrm{V}_{\text {Conc }}$ - concentration loss.

The resistance to electron flow through the anode, cathode and the interconnects and the resistance to ion flow through the electrolyte cause the Ohmic loss can be estimated from equation (15):

$\mathrm{V}_{\text {Ohm }}=\frac{\mathrm{i}_{\text {cell }}}{\mathrm{A}_{\text {cell }}}\left(\sigma_{\text {anode }} \cdot 1_{\text {anode }}+\sigma_{\text {cathode }} \cdot 1_{\text {cathode }}+\sigma_{\text {interconn }}\right.$.

$\left.\cdot 1_{\text {interconn }}+\sigma_{\text {electrolyte }} \cdot 1_{\text {electrolyte }}\right)$

where: $\mathrm{i}_{\text {cell }}$ is the cell current $[\mathrm{A}], \mathrm{A}_{\text {cell }}$ is the total active cell surface $\left[\mathrm{m}^{2}\right], \mathrm{l}_{\mathrm{i}}$ is the $\mathrm{i}$ - component thickness $[\mathrm{m}], \sigma_{\mathrm{i}}$ is the $\mathrm{i}-$ component resistivity calculated as a function of temperature (equations (16) - (19)) ${ }^{\mathbf{1 4}}$ :

$\sigma_{\text {anode }}=2.98 \cdot 10^{-5} \exp \left(-\frac{1392}{\mathrm{~T}}\right)$

$\sigma_{\text {cathode }}=8.114 \cdot 10^{-5} \exp \left(\frac{600}{\mathrm{~T}}\right)$

$\sigma_{\text {interconnectors }}=1.2568 \cdot 10^{-3} \exp \left(\frac{4690}{\mathrm{~T}}\right)$

$\sigma_{\text {electrolyte }}=2.94 \cdot 10^{-5} \exp \left(\frac{10350}{\mathrm{~T}}\right)$

While the cell current was calculated from equation (20):

$\mathrm{i}_{\text {cell }}=4 \cdot \mathrm{F} \cdot \mathrm{n}_{\mathrm{O}_{2 \text { required }}} \cdot \frac{1}{\mathrm{n}}$

where: $\mathrm{n}$ is the number of fuel cell in the first 90 -cells SOFC stack and the second 240-cells SOFC stack, respectively, $\mathrm{n}_{\mathrm{O}_{2} \text { required }}$ is the oxygen flow rate required calculated from equation (21):

$\mathrm{n}_{\mathrm{O}_{2 \text { required }}}=0.5 \cdot \mathrm{FU} \cdot \dot{\mathrm{n}}_{\mathrm{H}_{2, \text { equivalent }}}$

The activation loss is mainly associated with the slow rate of chemical reactions taking place on the surface of the electrodes. The activation voltage loss can be expressed by the equation (22):

$\mathrm{V}_{\text {act }}=\left(\frac{\mathrm{RT}}{2 \alpha_{\text {anode }} \mathrm{F}}\right) \ln \left(\frac{\mathrm{j}}{\mathrm{j}_{0, \text { anode }}}\right)-\left(\frac{\mathrm{RT}}{4 \alpha_{\text {cathode }} \mathrm{F}}\right) \ln \left(\frac{\mathrm{j}}{\mathrm{j}_{0, \text { cathode }}}\right)$

where: $\alpha$ is a pre-exponential factor for anode and cathode, $\mathrm{j}_{0}$ is the exchange current density $\mathrm{A}^{-2}$ given as follows (equations (23)-(24)):

$\mathrm{j}_{0, \text { anode }}=\mathrm{j}_{\mathrm{H}_{2}}^{*} \cdot\left(\frac{\mathrm{p}_{\mathrm{H}_{2}}}{\mathrm{p}_{\text {ref }}}\right) \cdot\left(\frac{\mathrm{p}_{\mathrm{H}_{2} \mathrm{O}}}{\mathrm{p}_{\text {ref }}}\right) \cdot \exp \left(-\frac{\mathrm{E}_{\text {anode }}}{\mathrm{RT}}\right)$

$\mathrm{j}_{0, \text { cathode }}=\mathrm{j}_{\mathrm{O}_{2}}^{*} \cdot\left(\frac{\mathrm{p}_{\mathrm{O}_{2}}}{\mathrm{p}_{\text {ref }}}\right)^{0.25} \cdot \exp \left(-\frac{\mathrm{E}_{\text {cathode }}}{\mathrm{RT}}\right)$

where: $p_{\text {ref }}$ is the system reference pressure, $p_{\text {ref }}=1$ bar, $p_{i}$ is the $\mathrm{i}$ - component partial pressure, $\mathrm{E}_{\text {anode/cathode }}$ is the anode or cathode energy activation $\mathrm{J}^{\mathrm{mol}}{ }^{-1}, \mathrm{j}^{*}$ is the pre-exponential factor $\mathrm{A}^{-2}$.

The concentration loss is associated with the mass transport limitations of the reacting species through the 
porous electrode pores during travel to the reaction sites. It depends of the gas species, thickness of the electrodes, porosity and tortuosity of the electrodes. The following form of the concentration loss was applied in Aspen Plus (equations (25)-(27)):

$\mathrm{V}_{\text {Conc }}=\mathrm{V}_{\text {Conc_anode }}+\mathrm{V}_{\text {Conc_cathode }}$

$\mathrm{V}_{\text {Conc_anode }}=-\frac{\mathrm{RT}}{2 \mathrm{~F}} \ln \left(1-\frac{\mathrm{j}}{\mathrm{j}_{\text {lim Anode }}}\right)+$

$+\frac{\mathrm{RT}}{2 \mathrm{~F}} \ln \left(1+\frac{\mathrm{p}_{\mathrm{H}_{2}} \cdot \mathrm{j}}{\mathrm{p}_{\mathrm{H}_{2} \mathrm{O}} \cdot \mathrm{j}_{\text {lim Anode }}}\right)$

$\mathrm{V}_{\text {Conc_cathode }}=-\frac{\mathrm{RT}}{4 \mathrm{~F}} \ln \left(1-\frac{\mathrm{j}}{\mathrm{j}_{\text {lim Cathode }}}\right)$

where: $\mathrm{j}_{\text {lim }}$ is the current density, which can be obtained with maximum fuel consumption during the reaction. The following equations (28) and (29) were used for the anode and cathode current density, respectively:

$\mathrm{j}_{\text {lim Anode }}=\frac{2 \cdot \mathrm{F} \cdot \mathrm{D}_{\text {eff, } \mathrm{H}_{2}-\mathrm{H}_{2} \mathrm{O}}}{\mathrm{R} \cdot \mathrm{T} \cdot \mathrm{l}_{\text {anode }}} \mathrm{p}_{\mathrm{H}_{2}}$
$\mathrm{j}_{\text {lim Cathode }}=\frac{4 \cdot \mathrm{F} \cdot \mathrm{D}_{\text {eff }, \mathrm{O}_{2}-\mathrm{N}_{2}}}{\mathrm{R} \cdot \mathrm{T} \cdot 1_{\text {cathode }}\left(\mathrm{p}-\frac{\mathrm{p}_{\mathrm{O}_{2}}}{\mathrm{p}}\right)} \mathrm{p}_{\mathrm{O}_{2}}$

where: $\mathrm{D}_{\text {eff, } \mathrm{i}}$ is the overall effective diffusion coefficient which was calculated for each gas using equations (30)-(31) ${ }^{\mathbf{1 5}}$ :

$\mathrm{D}_{\text {eff }, \mathrm{H}_{2}-\mathrm{H}_{2} \mathrm{O}}=\frac{\varepsilon}{\tau} \mathrm{D}_{\mathrm{H}_{2}-\mathrm{H}_{2} \mathrm{O}}$

$\mathrm{D}_{\text {eff, } \mathrm{O}_{2}-\mathrm{N}_{2}}=\frac{\varepsilon}{\tau} \mathrm{D}_{\mathrm{O}_{2}-\mathrm{N}_{2}}$

where: $\mathrm{D}_{\mathrm{ik}}$ is the ordinary binary diffusion coefficient for both anode and cathode (equations (32)-(33)) ${ }^{\mathbf{1 6}}$ :

$$
\begin{aligned}
\mathrm{D}_{\mathrm{H}_{2}-\mathrm{H}_{2} \mathrm{O}} & =\frac{0.00143 \cdot \mathrm{T}^{1.75}}{\mathrm{M}_{\mathrm{H}_{2}-\mathrm{H}_{2} \mathrm{O}}^{0.5} \cdot\left(\vartheta_{\mathrm{H}_{2}}^{1 / 3}+\vartheta_{\mathrm{H}_{2} \mathrm{O}}^{1 / 3}\right)^{2} \cdot \mathrm{p}} \\
\mathrm{D}_{\mathrm{O}_{2}-\mathrm{N}_{2}} & =\frac{0.00143 \cdot \mathrm{T}^{1.75}}{\mathrm{M}_{\mathrm{O}_{2}-\mathrm{N}_{2}}^{0.5} \cdot\left(\vartheta_{\mathrm{O}_{2}}^{1 / 3}+\vartheta_{\mathrm{N}_{2}}^{1 / 3}\right)^{2} \cdot \mathrm{p}}
\end{aligned}
$$

where: $\vartheta_{\mathrm{ik}}$ is the Fuller diffusion volume taken as 7.07; 12.7, 16.6 and 17.9 for $\mathrm{H}_{2}, \mathrm{H}_{2} \mathrm{O}, \mathrm{O}_{2}$ and $\mathrm{N}_{2}$, respectively ${ }^{17}$. $\mathrm{M}_{\mathrm{i}}$ is the molecular weight $\mathrm{kg} \cdot \mathrm{kmol}^{-1}$ for the gaseous component, $\varepsilon$ is the porosity and $\tau$ is the tortuosity of the electrodes.

$$
\begin{aligned}
\mathrm{M}_{\mathrm{H}_{2}-\mathrm{H}_{2} \mathrm{O}} & =\frac{2}{\frac{1}{\mathrm{M}_{\mathrm{H}_{2}}}+\frac{1}{\mathrm{M}_{\mathrm{H}_{2} \mathrm{O}}}} \\
\mathrm{M}_{\mathrm{O}_{2}-\mathrm{N}_{2}} & =\frac{2}{\frac{1}{\mathrm{M}_{\mathrm{O}_{2}}}+\frac{1}{\mathrm{M}_{\mathrm{N}_{2}}}}
\end{aligned}
$$

Model input parameters are presented in Table 1.

Table 1. Input parameters of the two-stage SOFC stacks power generation system model

\begin{tabular}{|l|c|c|}
\hline Model parameter & Value & Dimension \\
\hline Active single fuel cell surface & $1.278 \cdot 10^{-2}$ & {$\left[\mathrm{~m}^{2}\right]$} \\
\hline Anode thickness & $4.00 \cdot 10^{-5}$ & {$[\mathrm{~m}]$} \\
\hline Cathode thickness & $4.00 \cdot 10^{-5}$ & {$[\mathrm{~m}]$} \\
\hline Electrolyte thickness & $9.00 \cdot 10^{-5}$ & {$[\mathrm{~m}]$} \\
\hline Interconnection thickness & $5.00 \cdot 10^{-3}$ & {$[\mathrm{~m}]$} \\
\hline $\begin{array}{l}\text { Activation energy for } \\
\text { anode/cathode }\end{array}$ & $1.10 \cdot 10^{5} / 1.20 \cdot 10^{5}$ & {$\left[\mathrm{Jmol}^{-1}\right]$} \\
\hline Electrode porosity & $3.50 \cdot 10^{-1}$ & {$[-]$} \\
\hline Tortuosity & $3.80 \cdot 10^{1}$ & {$[-]$} \\
\hline $\begin{array}{l}\text { Pre-exponential factor } \\
\text { anode/cathode }\end{array}$ & $2.0710^{9} / 5.19 \cdot 10^{8}$ & {$\left[\mathrm{Am}^{-2}\right]$} \\
\hline
\end{tabular}

The Aspen Plus model calculated the voltage of a single fuel cell from the equation (14), while the current. $\mathrm{j}$, was calculated from the equation (36):

$\mathrm{j}=\frac{\mathrm{i}_{\text {cell }}}{\mathrm{A}}$

where: A is the active fuel cell surface. The flowchart of the cell voltage calculations applied in this study can be found in paper $^{3}$. Two stage SOFC stacks performances were predicted based on the presented above mathematical model implemented in Aspen Plus using a complex Define-Spec-Vary block functions.

The hierarchy of the calculations is shown in Figure 2:

\section{RESULTS AND DISCUSSION}

Several validations have been conducted in this study to obtain a confidence with the correctness of the simulation results. First, the system under $100 \%$ load was validated against project partners data ${ }^{\mathbf{1 8}}$. Later, the system under $47 \%$ load was validated and discussed in detail in the following section.

As seen in Table 2, the model results for $100 \%$ load are in good agreement with data obtained from project partner - sunfire ${ }^{\mathbf{1 8}}$. There is a slight difference for voltage, current and efficiency.

The model prediction results for $100 \%$ load presented in this work match very closely to data ${ }^{\mathbf{1 8}}$. In particular, the DC electrical power calculated for both stacks equalled to 2473 and $4557 \mathrm{~W}$, respectively for the first 90 - cells and second 240 - cells SOFC stacks indicate that the quantity of electricity produced was close to the level of data ${ }^{\mathbf{1 8}}$.

The staged SOFC stacks power generation system performance under $47 \%$ load is depicted in Table 3. The single cell voltage for both stacks increased in comparison to the case under $100 \%$ load. As a consequence, the electrical power decreased almost half for both 90 - cells and 240 - cells SOFC stacks. Differences in comparison with data ${ }^{18}$ under $47 \%$ load are higher and they are in the order of 7-8\%. It was the result of lack of knowledge of the porosity and tortuosity of the electrodes values. Nevertheless, it should be underlined good agreement in prediction the current for both stack.

A second validation of the model was conducted using data $^{18}$ for the considered system operating at the same natural gas composition. The gas compositions at the inlet to the anode side of the first SOFC stack "ISM1" 


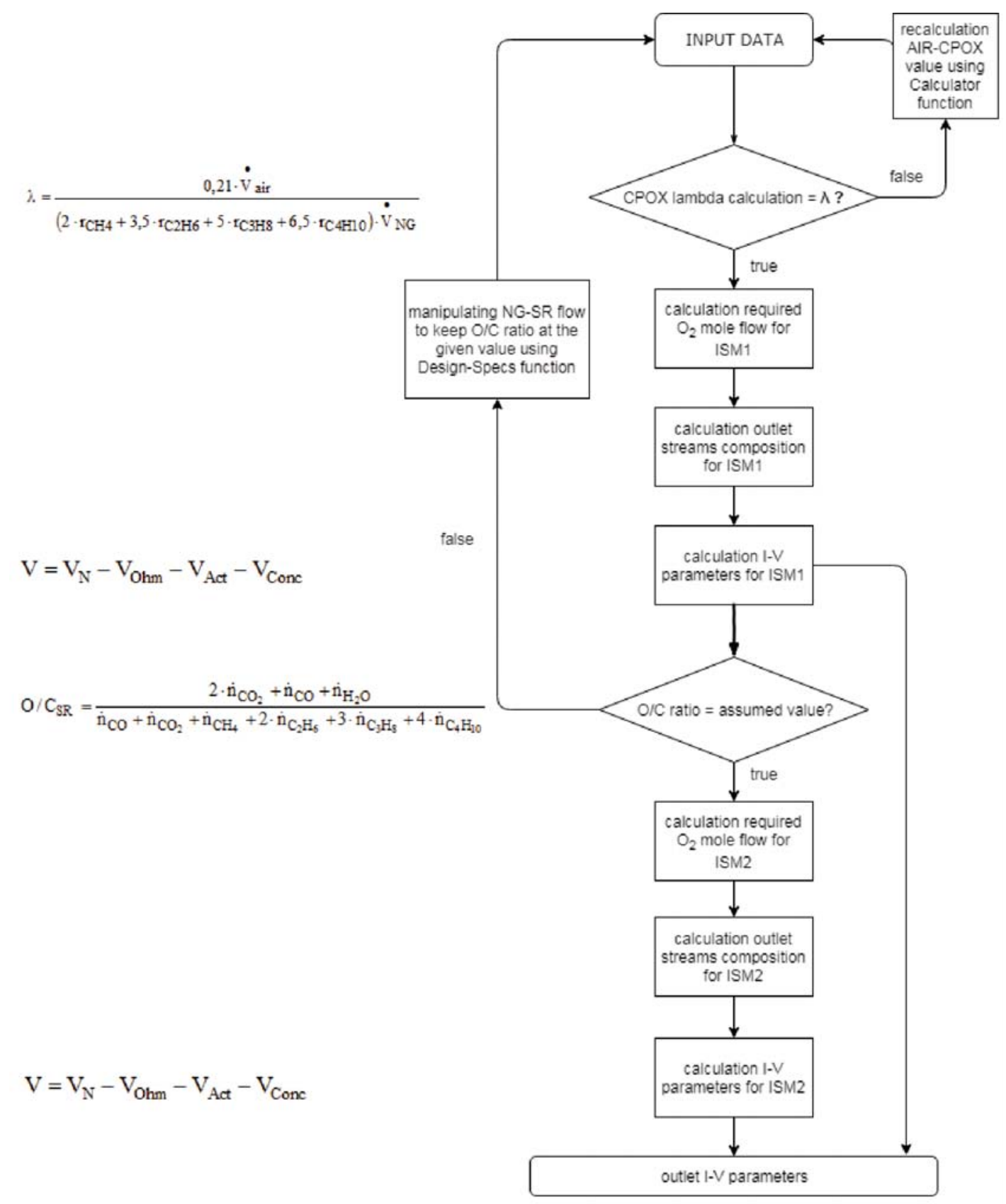

Figure 2. Hierarchy of cell voltage calculations

Table 2. Model results for $100 \%$ load compared to data ${ }^{18}$ at operating temperature of $830^{\circ} \mathrm{C}$ and fuel utilization of $75 \%$

\begin{tabular}{|c|c|c|c|c|}
\hline Parameter & Dimensions & Model results & Comparative simulation data ${ }^{13}$ & Deviation [\%] \\
\hline \multicolumn{5}{|c|}{90 - cells SOFC stack - ISM1 } \\
\hline Voltage - single cell & {$[\mathrm{V}]$} & 0.71 & 0.70 & $1.17 \%$ \\
\hline Voltage - stack & [V] & 63.74 & 62.67 & $1.70 \%$ \\
\hline Current & {$[\mathrm{A}]$} & 38.78 & 38.70 & $0.21 \%$ \\
\hline Electrical power & [W] & 2473 & 2425 & $1.98 \%$ \\
\hline \multicolumn{5}{|c|}{240 - cells SOFC stack - ISM2 } \\
\hline Voltage - single cell & {$[\mathrm{V}]$} & 0.73 & 0.77 & $5.74 \%$ \\
\hline Voltage - stack & {$[\mathrm{V}]$} & 174.19 & 183.80 & $5.23 \%$ \\
\hline Current & {$[\mathrm{A}]$} & 26.16 & 26.10 & $0.23 \%$ \\
\hline \multirow[t]{2}{*}{ Electrical power } & [W] & 4557 & 4797 & $5.00 \%$ \\
\hline & & Overall & & \\
\hline Gross electrical efficiency & [\%] & 43.07 & 44.50 & $3.21 \%$ \\
\hline
\end{tabular}

were compared and are presented in Table 4 and 5, respectively for the system working under $100 \%$ and $47 \%$.

The model results obtained by the Aspen Plus of the concentrations of the main components (shown in Tables 4 and 5) are in agreement with the data ${ }^{\mathbf{1 8}}$. Thus, it can be summarized that the results obtained from the present study show very good agreement with the data demonstrating the model's capability of simulating performance of the staged two SOFC stacks based power generation system.

The validated model was run using different levels of fuel utilization factor, FU, equal to $0.75,0.80$ and 0.85 at the current density in the range of $0-6000 \mathrm{~A}^{-2}$ assuming that the system was maintained at 800,830 
Table 3. Model results for $47 \%$ load compared to data ${ }^{18}$ at operating temperature of $830^{\circ} \mathrm{C}$ and fuel utilization of $75 \%$

\begin{tabular}{|c|c|c|c|c|}
\hline Parameter & Dimensions & Model results & Comparative simulation data ${ }^{13}$ & Deviation [\%] \\
\hline \multicolumn{5}{|c|}{90 - cells SOFC stack - ISM1 } \\
\hline Voltage - single cell & {$[\mathrm{V}]$} & 0.89 & 0.82 & $8.86 \%$ \\
\hline Voltage - stack & [V] & 80.46 & 73.91 & $8.86 \%$ \\
\hline Current & {$[\mathrm{A}]$} & 16.47 & 16.50 & $0.18 \%$ \\
\hline Electrical power & [W] & 1325 & 1220 & $8.61 \%$ \\
\hline \multicolumn{5}{|c|}{240 - cells SOFC stack - ISM2 } \\
\hline Voltage - single cell & [V] & 0.90 & 0.84 & $7.17 \%$ \\
\hline Voltage - stack & {$[\mathrm{V}]$} & 216.10 & 201.64 & $7.17 \%$ \\
\hline Current & {$[\mathrm{A}]$} & 11.1 & 11.10 & $0.00 \%$ \\
\hline \multirow[t]{2}{*}{ Electrical power } & {$[\mathrm{W}]$} & 2399 & 2238 & $7.19 \%$ \\
\hline & & Overall & & \\
\hline Gross electrical efficiency & {$[\%]$} & 53.76 & 49.59 & $7.76 \%$ \\
\hline
\end{tabular}

Table 4. Comparison of anode inlet stream results for $100 \%$ load at operating temperature of $830^{\circ} \mathrm{C}$ and $\mathrm{FU}$ of $75 \%$ from simulations and literature data ${ }^{13}$

\begin{tabular}{|c|c|c|c|c|}
\hline \multirow[b]{2}{*}{ Parameter } & \multirow[b]{2}{*}{ Dimensions } & \multicolumn{2}{|c|}{ ST1-AN-IN } & \multirow[b]{2}{*}{ Deviation [\%] } \\
\hline & & Model results & $\begin{array}{c}\text { Comparative simulation } \\
\text { data }^{13}\end{array}$ & \\
\hline Flow rate & {$\left[\mathrm{mol} / \mathrm{s}^{-1}\right]$} & 0.0455 & 0.0457 & $0.42 \%$ \\
\hline Temperature & {$\left[{ }^{\circ} \mathrm{C}\right]$} & 709.59 & 710.27 & $0.10 \%$ \\
\hline Pressure & [bar] & 1.04 & 1.04 & $0.00 \%$ \\
\hline \multicolumn{5}{|c|}{ Flow composition } \\
\hline $\mathrm{CH}_{4}$ & {$\left[\mathrm{~mol} \cdot \mathrm{mol}^{-1}\right]$} & 0.0112 & 0.0109 & $2.96 \%$ \\
\hline $\mathrm{C}_{2} \mathrm{H}_{6}$ & {$\left[\mathrm{~mol}^{\prime} \mathrm{mol}^{-1}\right]$} & $5.95 \cdot 10^{-8}$ & $5.59 \cdot 10^{-8}$ & Trace \\
\hline $\mathrm{C}_{3} \mathrm{H}_{8}$ & {$\left[\mathrm{~mol}^{\prime} \mathrm{mol}^{-1}\right]$} & $1.28 \cdot 10^{-12}$ & $1.19 \cdot 10^{-12}$ & Trace \\
\hline $\mathrm{C}_{4} \mathrm{H}_{10}$ & {$\left[\mathrm{molmol}^{-1}\right]$} & $2.72 \cdot 10^{-17}$ & $1.67 \cdot 10^{-15}$ & Trace \\
\hline $\mathrm{O}_{2}$ & {$\left[\mathrm{~mol}^{\prime} \mathrm{mol}^{-1}\right]$} & $2.48 \cdot 10^{-23}$ & $3.03 \cdot 10^{-15}$ & Trace \\
\hline $\mathrm{N}_{2}$ & {$\left[\mathrm{~mol}^{\prime} \mathrm{mol}^{-1}\right]$} & 0.4478 & 0.4475 & $0.06 \%$ \\
\hline $\mathrm{H}_{2}$ & {$\left[\mathrm{~mol}^{\prime} \mathrm{mol}^{-1}\right]$} & 0.3278 & 0.3288 & $0.29 \%$ \\
\hline $\mathrm{H}_{2} \mathrm{O}$ & {$\left[\mathrm{mol}^{\prime} \mathrm{mol}^{-1}\right]$} & 0.0320 & 0.0314 & $1.79 \%$ \\
\hline $\mathrm{CO}$ & {$\left[\mathrm{mol}^{\mathrm{mol}}{ }^{-1}\right]$} & 0.1572 & 0.1572 & $0.00 \%$ \\
\hline $\mathrm{CO}_{2}$ & {$\left[\mathrm{~mol} \mathrm{~mol}^{-1}\right]$} & 0.0240 & 0.0242 & $0.87 \%$ \\
\hline
\end{tabular}

Table 5. Anode inlet stream results for $47 \%$ load at operating temperature of $830^{\circ} \mathrm{C}$ and fuel utilization of $75 \%$

\begin{tabular}{|c|c|c|c|c|}
\hline \multirow[b]{2}{*}{ Parameter } & \multirow[b]{2}{*}{ Dimensions } & \multicolumn{2}{|c|}{ ST1-AN-IN } & \multirow[b]{2}{*}{ Deviation [\%] } \\
\hline & & Model results & Comparative simulation data ${ }^{13}$ & \\
\hline Flow rate & {$\left[\mathrm{mol} \mathrm{s}^{-1}\right]$} & 0.0193 & 0.0194 & $0.41 \%$ \\
\hline Temperature & {$\left[{ }^{\circ} \mathrm{C}\right]$} & 709.59 & 710.27 & $0.09 \%$ \\
\hline Pressure & [bar] & 1.04 & 1.04 & $0.00 \%$ \\
\hline \multicolumn{5}{|c|}{ Flow composition } \\
\hline $\mathrm{CH}_{4}$ & {$\left[\mathrm{~mol}^{\prime} \mathrm{mol}^{-1}\right]$} & 0.0112 & 0.0109 & $2.87 \%$ \\
\hline $\mathrm{C}_{2} \mathrm{H}_{6}$ & {$\left[\mathrm{~mol}^{\prime} \mathrm{mol}^{-1}\right]$} & $5.9510^{-8}$ & $5.60 \cdot 10^{-8}$ & Trace \\
\hline $\mathrm{C}_{3} \mathrm{H}_{8}$ & {$\left[\mathrm{~mol} \cdot \mathrm{mol}^{-1}\right]$} & $1.28 \cdot 10^{-12}$ & $1.19 \cdot 10^{-12}$ & Trace \\
\hline $\mathrm{C}_{4} \mathrm{H}_{10}$ & {$\left[\mathrm{~mol} \cdot \mathrm{mol}^{-1}\right]$} & $2.72 \cdot 10^{-17}$ & $1.67 \cdot 10^{-15}$ & Trace \\
\hline $\mathrm{O}_{2}$ & {$\left[\mathrm{~mol} \mathrm{~mol}^{-1}\right]$} & $2.4810^{-23}$ & $3.0310^{-15}$ & Trace \\
\hline $\mathrm{N}_{2}$ & {$\left[\mathrm{~mol} \cdot \mathrm{mol}^{-1}\right]$} & 0.4478 & 0.4475 & $0.06 \%$ \\
\hline $\mathrm{H}_{2}$ & {$\left[\mathrm{~mol}^{\prime} \mathrm{mol}^{-1}\right]$} & 0.3278 & 0.3288 & $0.29 \%$ \\
\hline $\mathrm{H}_{2} \mathrm{O}$ & {$\left[\mathrm{mol} \cdot \mathrm{mol}^{-1}\right]$} & 0.0320 & 0.0314 & $1.80 \%$ \\
\hline $\mathrm{CO}$ & {$\left[\mathrm{mol} \cdot \mathrm{mol}^{-1}\right]$} & 0.1572 & 0.1572 & $0.00 \%$ \\
\hline $\mathrm{CO}_{2}$ & {$\left[\mathrm{~mol}^{\mathrm{mol}}{ }^{-1}\right]$} & 0.0240 & 0.0242 & $0.87 \%$ \\
\hline
\end{tabular}

and $860^{\circ} \mathrm{C}$. Increasing the fuel utilization factor implies that more hydrogen was consumed by SOFC stacks and as a consequence converting more chemical energy into electrical energy. However, in the considered system, the analysis showed negligible differences in cell voltage values at constant temperature and variable fuel utilization. It should be underlined that the increase in the stack temperature caused an increase the voltage along the full range of current $0-6000 \mathrm{Am}^{-2}$. Fig. 3 shows that increasing the temperature from $800^{\circ} \mathrm{C}$ to $860^{\circ} \mathrm{C}$ influence significantly on the voltage increases at the current density range from 0 to $6000 \mathrm{Am}^{-2}$.

Growth of the operating temperature of each SOFC sub-system leads to an increase in stack power (Fig. 4). The temperature increases from 800 to $860^{\circ} \mathrm{C}$ caused shift of a peak power towards higher current density values, which means lower values of the single cell voltage. While, it is desirable with regards to operating costs, to operate the SOFC stack at high voltage and efficiency. Therefore, there has to be a trade-off between voltage, efficiency and power.

The effect of varying pressure is displayed in Fig. 5 and 6 for both SOFC stacks sub-systems. The pressure was increased from 1.035 bar to 2.070 bar. Fig. 5 presents the effect of varying cell temperature and pressure of the supplied fuel on a single fuel cell. The SOFC stacks pressure and temperature showed significant effect on cell voltage. Increasing pressure from 1.035 to 2.070 bar a higher cell voltage was obtained within the given temperature value of 800,830 and $860^{\circ} \mathrm{C}$. The voltage increase was significant within the first 90 cells SOFC stack and the second one with 240 cells. 


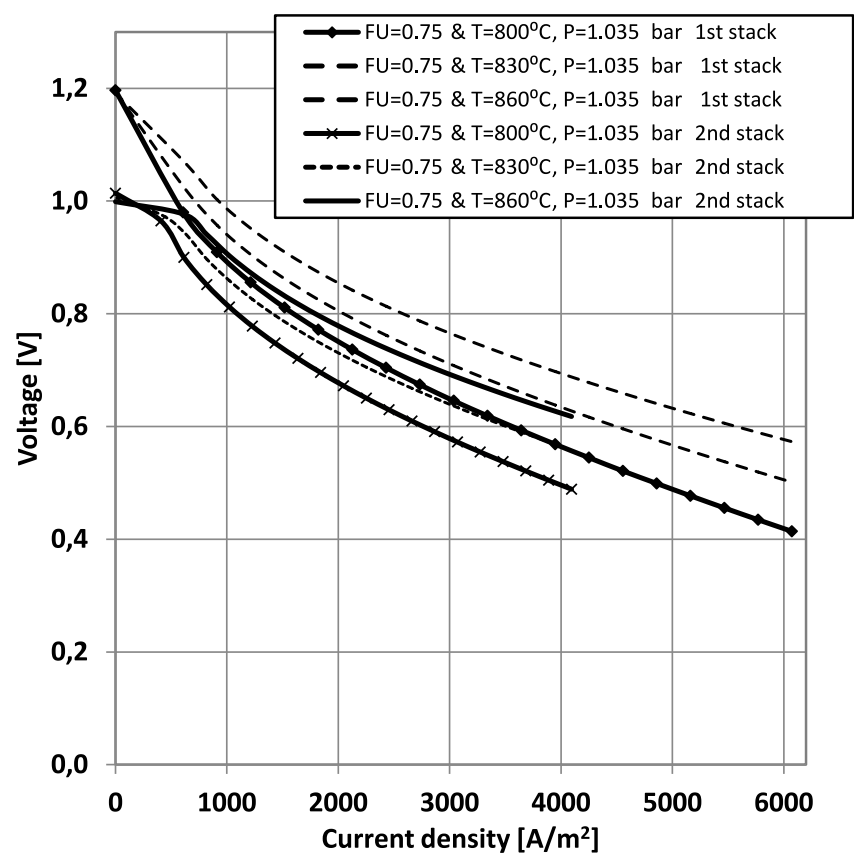

Figure 3. Effect of the operating temperature for staged SOFC stacks "ISM1" and "ISM2" on the single cell voltage

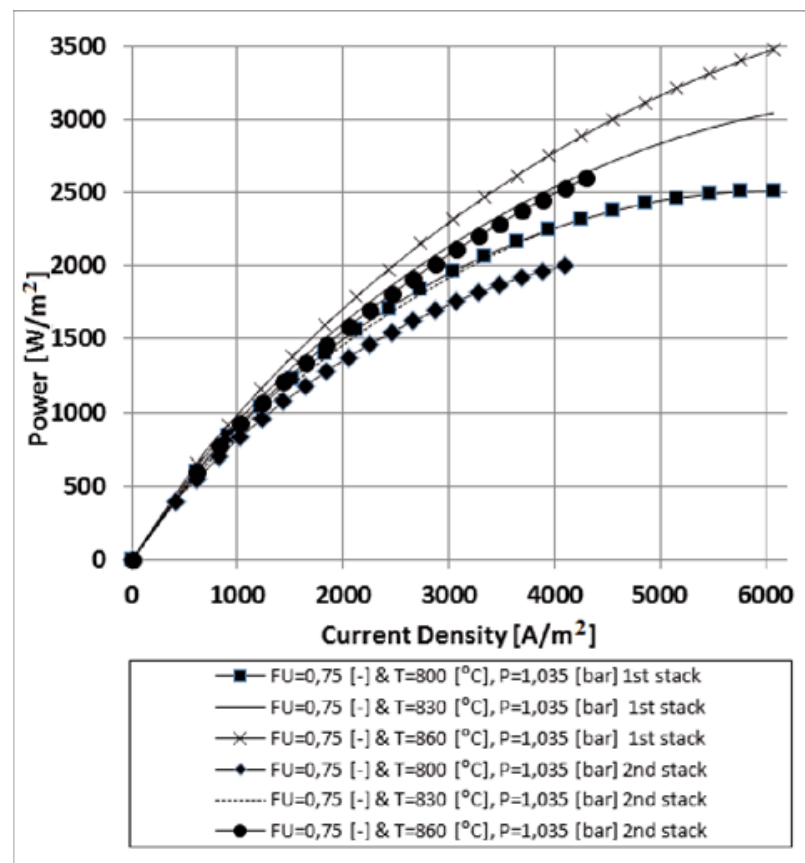

Figure 4. Effect of current density on power at fuel utilization of 0.75 for two-stage SOFC stacks "ISM1" and "ISM2" in the power generation system at three level of operating temperature

Maintaining a constant fuel utilization at higher pressure provides an increase of the steam reforming efficiency, which in consequence affects the increase of the single cell voltage in the second SOFC stack sub-system. It should be underlined that Figs. 2-5 do not represent the correct relationship between the single cell voltage for both staged SOFC stacks in the power generation system. Therefore, it was proposed to evaluate the system performance based on the parameter depicting the relationship between two-stage SOFC stacks as the ratio of the voltage of the individual cell in both stacks as shown in Fig. 7.
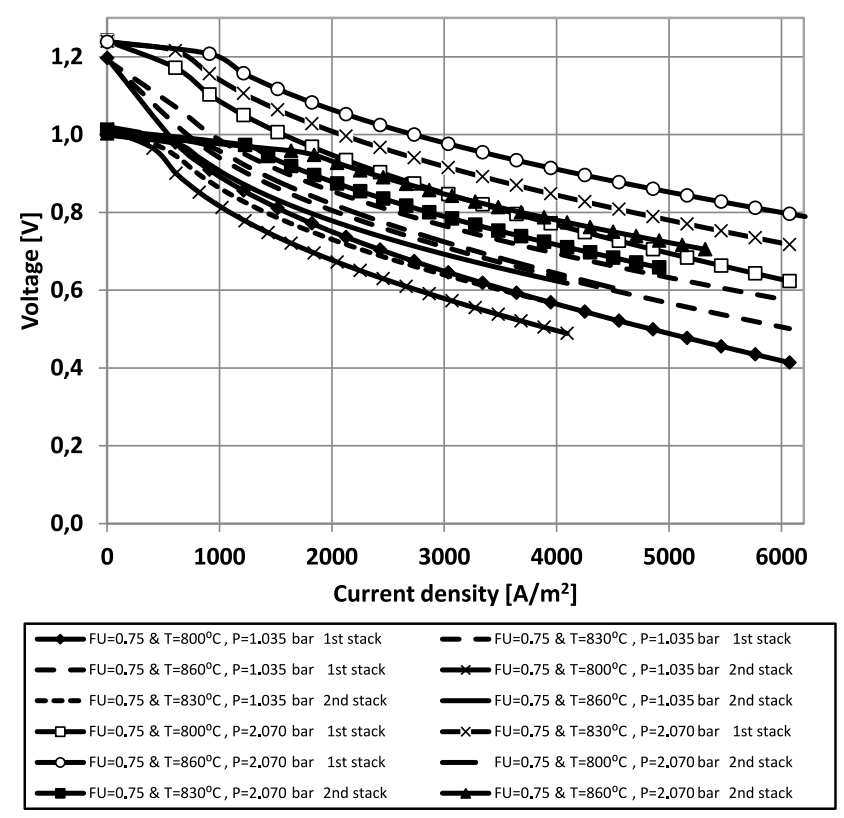

Figure 5. Effect of current density on voltage at fuel utilization of 0.75 for two-stage SOFC stacks "ISM1" and "ISM2" dependent of different values of the operating pressure and temperature
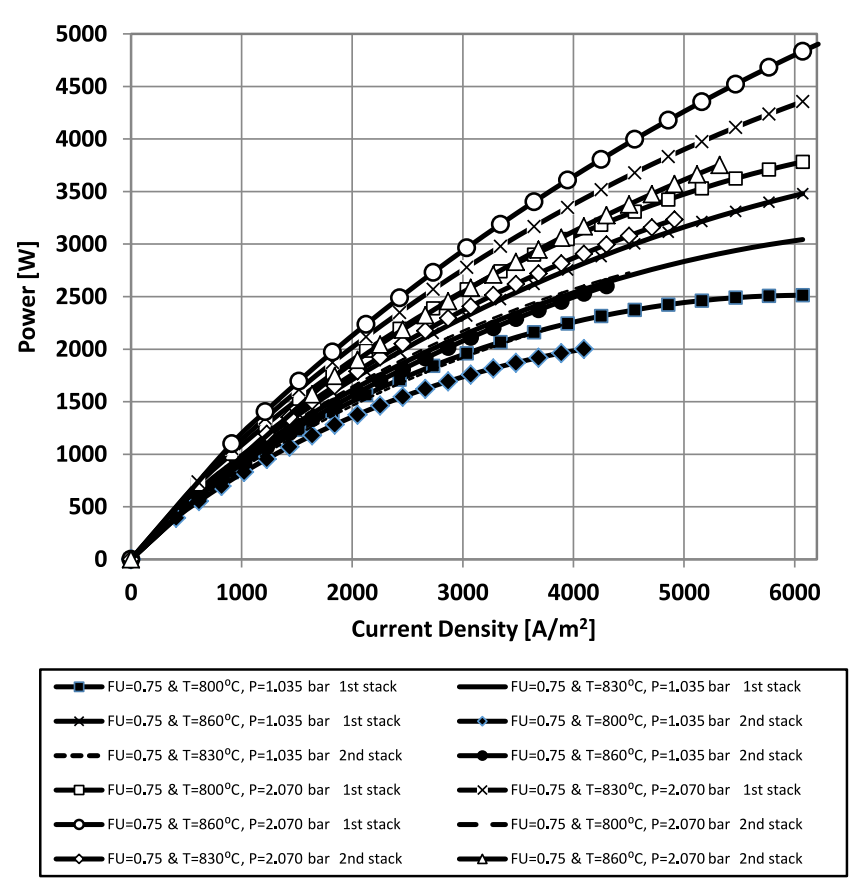

Figure 6. Effect of current density on power at fuel utilization of 0.75 for two-stage SOFC stacks "ISM1" and "ISM2" dependent of different values of the operating pressure and temperature

It was observed that the open circuit voltage was higher in case of the first SOFC stack. In addition, it was noticed (Fig. 6) that the voltage values on both SOFC stacks were quite similar in the operational range of current density 1000-2000 A.m ${ }^{-2}$, which is in the area of SOFC development system interest. Above the current density of $3000 \mathrm{~A} \cdot \mathrm{m}^{-2}$, the single cell voltage in the second SOFC sub-system decreases at a slower rate according to the increase of the SOFC temperature. Most visible changes were observed for the lowest operating temperature of $800^{\circ} \mathrm{C}$. As the temperature increases, the 
magnitude of the voltage changes in the range of higher current density decreases.

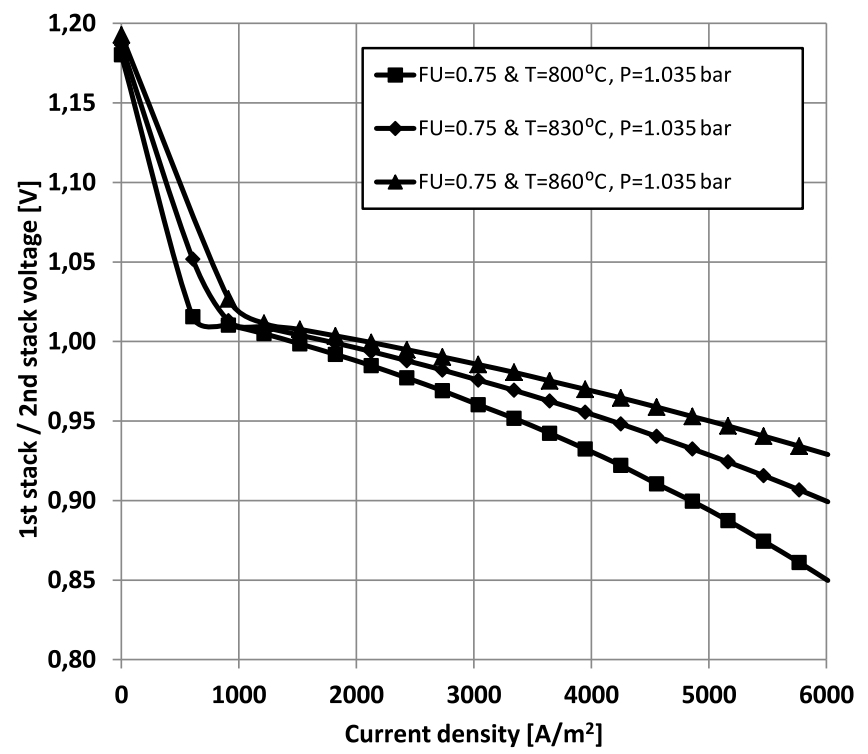

Figure 7. The ratio of the cell voltage in two-stage SOFC stacks "ISM1" and "ISM2" sub-systems referenced to the current density of the first 90 - cells SOFC stack

\section{CONCLUSIONS}

This paper has focused on developing a complete system included two SOFC stacks (90 and 240 cells per stack) in serial connection. The computer experimental numerical analysis of two-stage SOFC stacks in the 5 $\mathrm{kW}$ combined heat and power system fed by natural gas has been developed in Aspen Plus ${ }^{\mathrm{TM}}$ Simulator and validated with published data ${ }^{\mathbf{1 8}}$. Two different types of fuel reforming processes: $\mathrm{CPO}_{\mathrm{x}}$ and steam reforming were implemented. The STAGE-SOFC model was constructed using the existing Aspen Plus ${ }^{\mathrm{TM}}$ functions and process simulator tools such as Spec Design and Calculator blocks, which allow to include the electrochemistry, the diffusion phenomena and the reforming kinetics in detail. Using them, the influence of the fuel utilization, temperature and pressure on the SOFC stacks performance under part $(47 \%)$ and full $(100 \%)$ loads were investigated. The electrochemical performance ( $\mathrm{I}-\mathrm{V}$ curve) was analysed in range $0-6000 \mathrm{~A}^{-2}$. The influence of temperature and pressure on the cell voltage was also considered. To evaluate the STAGE-SOFC system performance the ratio of the voltage of the individual cell in both stacks was reviewed.

In conclusion, a complete techno-economic modelling of the system is necessary to provide more insight regarding the capital cost and the operating cost based on the operating range investigated in this paper. This kind of study is planned to conduct over the entire life time of the whole system. This would definitely identify the benefits of the system over other conventional power generation systems. The complete STAGE-SOFC model included more detailed analysis of the transient behaviour and then, the optimization of the plant components can be performed in future work using Aspen Dynamics Simulator.

\section{NOMENCLATURE}

\begin{tabular}{|c|c|}
\hline $\mathrm{A}_{\text {cell }}$ & - total active fuel cell surface $\left[\mathrm{m}^{2}\right]$ \\
\hline $\mathrm{D}_{\mathrm{i}, \mathrm{k}}$ & $\begin{array}{l}\text { - ordinary binary diffusion coefficient } \\
{\left[\mathrm{m}^{2} \mathrm{~s}^{-1}\right]}\end{array}$ \\
\hline $\mathrm{D}_{\text {eff,i }}$ & $\begin{array}{l}\text { - overall effective diffusion coefficient for } \\
\mathrm{i} \text { - component }\left[\mathrm{m}^{2} \mathrm{~s}^{-1}\right]\end{array}$ \\
\hline $\mathrm{E}_{\text {anode/cathode }}$ & $\begin{array}{l}- \text { anode or cathode energy activation } \\
{\left[\mathrm{J} \cdot \mathrm{mol}^{-1}\right]}\end{array}$ \\
\hline $\mathrm{F}$ & - Faraday's constant $\left[\mathrm{C}^{\prime} \mathrm{mol}^{-1}\right]$ \\
\hline FU & - fuel utilization factor \\
\hline $\mathrm{G}_{\mathrm{i}}^{0}$ & - molar Gibbs free energy of formation, \\
\hline $\mathrm{i}$ & - component $\left[\mathrm{J} \cdot \mathrm{mol}^{-1}\right]$ \\
\hline $\mathrm{h}_{\mathrm{i}}$ & $\begin{array}{l}\text { - molar enthalpy of } i \text { component } \\
{[\mathrm{J} / \mathrm{mol}]}\end{array}$ \\
\hline $\mathrm{h}_{\mathrm{k}}$ & $\begin{array}{l}\text { - molar enthalpy of } k \text { component } \\
{[\mathrm{J} / \mathrm{mol}]}\end{array}$ \\
\hline $\mathrm{i}_{\text {cell }}$ & - cell current $[\mathrm{A}]$ \\
\hline $\mathrm{i}$ & - species $\mathrm{H}_{2}, \mathrm{H}_{2} \mathrm{O}, \mathrm{O}_{2}$ \\
\hline $\mathrm{j}$ & - density current $\left[\mathrm{A} \cdot \mathrm{m}^{-2}\right]$ \\
\hline $\mathrm{j}_{0}$ & - exchange density current $\left[\mathrm{A} \cdot \mathrm{m}^{-2}\right]$, \\
\hline $\mathrm{j}^{*}$ & - pre-exponential factor $\left[\mathrm{A} \cdot \mathrm{m}^{-2}\right]$ \\
\hline $\mathrm{j}_{\text {lim }}$ & $\begin{array}{l}\text { - current density at maximum fuel } \\
\text { consumption }\left[\mathrm{A}^{-2} \mathrm{~m}^{-2}\right]\end{array}$ \\
\hline$l_{\text {anode }}$ & - anode thickness $[\mathrm{m}]$ \\
\hline $1_{\text {cathode }}$ & - cathode thickness $[\mathrm{m}]$ \\
\hline $1_{\text {electrolyte }}$ & - electrolyte thickness [m] \\
\hline $1_{\text {interconn }}$ & - interconnectors thickness $[\mathrm{m}]$, \\
\hline LHV & - lower heating value $\left[\mathrm{MJ} / \mathrm{m}^{3}\right]$ \\
\hline $\mathrm{M}_{\mathrm{i}}$ & - molar mass of species $i\left[\mathrm{~kg} \cdot \mathrm{mol}^{-1}\right]$, \\
\hline$\dot{n}_{i}$ & - molar flow rate of $i$ component $\left[\mathrm{mol}^{-1}\right]$ \\
\hline$\dot{n}_{k}$ & - molar flow rate of $k$ component $\left[\mathrm{mol} \cdot \mathrm{s}^{-1}\right]$, \\
\hline $\mathrm{n}_{\mathrm{CH}_{4, \text { in }}}$ & $\begin{array}{l}\text { - molar flow rate of } \mathrm{H}_{2} \text { that could be } \\
\text { produced from the } \mathrm{CH}_{4}\left[\mathrm{~mol} \cdot \mathrm{s}^{-1}\right]\end{array}$ \\
\hline $\mathrm{n}_{\mathrm{CO}_{\text {in }}}$ & $\begin{array}{l}\text { - molar flow rate of } \mathrm{H}_{2} \text { that could be } \\
\text { produced from the } \mathrm{CO}\left[\mathrm{mol}^{-1}{ }^{-1}\right]\end{array}$ \\
\hline$\dot{\mathrm{n}}_{\mathrm{H}_{2, \text { consumed }}}$ & - molar flow rate of $\mathrm{H}_{2}$ consumed $\left[\mathrm{mol} \cdot \mathrm{s}^{-1}\right.$ ], \\
\hline$\dot{\mathrm{n}}_{\mathrm{H}_{2, \text { equivalent }}}$ & - equivalent $\mathrm{H}_{2}$ molar flow rate $\left[\mathrm{mol} \mathrm{s}^{-1}\right]$, \\
\hline $\mathrm{n}_{\mathrm{H}_{2, \text { in }}}$ & - molar flow rate of $\mathrm{H}_{2}\left[\mathrm{~mol} \cdot \mathrm{s}^{-1}\right]$ \\
\hline$\dot{\mathrm{n}}_{\mathrm{O}_{2, \text { required }}}$ & - required $\mathrm{O}_{2}$ molar flow rate $\left[\mathrm{mol}^{-1} \mathrm{~s}^{-1}\right.$, \\
\hline $\mathrm{p}$ & - pressure [bar], \\
\hline $\mathrm{p}_{\mathrm{i}}$ & $\begin{array}{l}\text { - partial pressure of gaseous } \\
\mathrm{i} \text { - component [bar] }\end{array}$ \\
\hline$p_{\text {ref }}$ & - system reference pressure [bar], \\
\hline $\mathrm{P}_{\mathrm{el}, \mathrm{AC}}$ & - AC electrical power [W], \\
\hline $\mathrm{R}$ & - universal gas constant $\left[\mathrm{Jkmol}^{-1} \mathrm{~K}^{-1}\right]$, \\
\hline$r_{\text {anode }}$ & - anode resistance $[\Omega]$ \\
\hline$r_{\text {cathode }}$ & - cathode resistance $[\Omega]$ \\
\hline$r_{\text {electrolyte }}$ & - electrolyte resistance $[\Omega]$ \\
\hline$r_{\text {interconnectors }}$ & - interconnectors resistance $[\Omega]$, \\
\hline $\mathrm{T}$ & - temperature $[\mathrm{K}]$ \\
\hline V & - voltage $[\mathrm{V}]$ \\
\hline $\mathrm{V}_{\text {Act }}$ & - activation loss [V], \\
\hline $\mathrm{V}_{\text {Conc }}$ & - concentration loss [V], \\
\hline $\mathrm{V}_{\mathrm{N}}$ & - Nernst voltage [V], \\
\hline $\mathrm{V}_{\mathrm{Ohm}}$ & - Ohmic voltage loss [V] \\
\hline $\mathrm{y}_{\mathrm{i}}$ & $\begin{array}{l}\text { - volume fraction of } i \text { - component }[-] \text {, } \\
\text { - volume flow }\left[\mathrm{m}^{3} / \mathrm{s}\right]\end{array}$ \\
\hline
\end{tabular}




\section{Greek symbols}

a

- conversion energy coefficient into electrical one

$\eta_{\text {el, gross }} \quad-$ gross electrical efficiency

$\tau$ - tortuosity factor

$\vartheta_{\mathrm{ik}} \quad-$ Fuller diffusion volume $\left[\mathrm{m}^{2} \cdot \mathrm{s}^{-1}\right]$,

$\Delta \bar{g}_{\mathrm{f}} \quad-$ molar Gibbs free energy of formation $\left[\mathrm{J} \cdot \mathrm{mol}^{-1}\right]$,

$\sigma_{\mathrm{i}} \quad-$ resistivity of $i$ component, $[\Omega \cdot \mathrm{m}]$.

\section{ACKNOWLEDGEMENTS}

The research programme leading to these results received funding from the European Union's Seventh Framework Programme (FP7/2007-2013) for the Fuel Cells and Hydrogen Joint Undertaking (FCH JU) under grant agreement $\mathrm{n}^{\circ}$ [621213]. Information contained in the paper reflects only view of the authors. The FCH $\mathrm{JU}$ and the Union are not liable for any use that may be made of the information contained therein. The work was also financed from the Polish research funds awarded for the project No. 3126/7.PR/2014/2 of international cooperation within STAGE-SOFC in years 2014-2017.

Special thanks for dr Oliver Posdziech from sunfire.

\section{LITERATURE CITED}

1. Buonomano, A., Calise, F., d'Accadia, M.D., Palombo, A. \& Vicidomini, M. (2015). Hybrid solid oxide fuel cells - gas turbine systems for combined heat and power: a review, Applied Energy, 156, 32-85. DOI: 10.1016/j.apenergy.2015.06.027.

2. Araki, T., Ohba, T., Takezawa, S., Onda, K. \& Sakaki, Y. (2006). Cycle analysis of planar SOFC power generation with serial connection of low and high temperature SOFCs, $J$. Power Sourc. 158, 52-59. DOI: 10.1016/j.jpowsour.2005.09.003.

3. Musa, A. \& De Paepe, M. (2008). Performance of combined internally reformed intermediate/high temperature SOFC cycle compared to internally reformed two-staged intermediate temperature SOFC cycle, International J. Hydrog. Energy, 33, 4665-4672. DOI: 10.1016/j.ijhydene.2008.05.093.

4. Mushtaq, U., Kim, D.W., Yun, U.J., Lee, J.W., Lee, S.B., Park, S.J., Song, R.H., Kim, G. \& Lim, T.H. (2015). Effect of cathode geometry on the electrochemical performance of flat tubular segmented in series (SIS) solid oxide fuel cell, International J. Hydrog. Energy, 40, 6207-6215. DOI: 10.1016/j. ijhydene.2015.03.040.

5. An, Y.T., Ji, M.J., Seol, K.H., Hwang, H.J., Parck, E. \& Choi, B.H. (2014). Characteristics of flat tubular ceramic supported segmented in series solid oxide fuel cell on all sides laminating using decalcomania method, J. Power Sourc. 262, 323-327. DOI: 10.1016/j/jpowsour.2014.03.136.

6. Ding, J. \& Liu, J. (2009). A novel design and performance of cone shaped tubular anode supported segmented in series solid oxide fuel cell stack, J. Power Sourc. 193, 769-773. DOI: 10.1016/j.jpowsour.2009.04.049.

7. Bai, Y., Wang, Ch., Ding, J., Jin, Ch. \& Liu, J. (2010). Direct operation of cone shaped anode supported segmented in series solid oxide fuel cell stack with methane, J. Power Sourc. 195, 3882-3886. DOI: 10.1016/j.jpowsour.2009.12.110.

8. Fujita, K., Seyama, T., Sobue, T. \& Matsuzaki, Y. (2012). Development of segmented in series type solid oxide fuel cells for residentiaon applications, Energy Procedia, 28, 153-161. DOI: 10.1016/j.egypro.2012.08.049.

9. Kupecki, J., Skrzypkiewicz, M., Wierzbicki, M. \& Stepien, M. (2017). Experimental and numerical analysis of a serial connection of two SOFC stacks in a micro-CHP system fed by biogas, International J. Hydrog. Energy, 42, 3487-3497. DOI: 10.1016/j.ijhydene.2016.07.222.

10. Anyenya, G.A., Sullivan, N.P., Braun, R.J. (2017). Modeling and simulation of a novel $4.5 \mathrm{kWe}$ multi-stack solid oxide fuel cell prototype assembly for combined heat and power, Energy Conversion and Management, 140, 247-259. DOI: 10.1016/j.enconman.2017.02.071.

11. Posdziech, O. System concepts and BoP components, Staxera/sunfire GmBH, http://slideplayer.com/slide/8883912/

12. Schimanke, D., Posdziech, O., Mai, B.E., Kluge, S., Strohbach, T. \& Wunderlich, Ch. (2011). Demonstration of a highly efficient SOFC system with Combined Partial Oxidation and Steam Reforming, ECS Transactions, 35, 1, 231-242. DOI: $10.1149 / 1.3569998$.

13. Minutilloa, M., Perna, A. \& Jannelli, E. (2014). SOFC and MCFC system level modeling for hybrid plants performance prediction, International J. Hydrog. Energy, 39, 21688-21699. DOI: 10.1016/j.ijhydene.2014.09.082.

14. Cali, M., Santarelli, M.G.L. \& Leone, P. (2006). Computer experimental analysis of the CHP performance of a $100 \mathrm{~kW}_{\mathrm{e}}$ SOFC Field Unit by a factorial design, J. Power Sourc. 156, 400-413. DOI: 10.1016/j.jpowsour.2005.06.033.

15. Chan, S.H., Khor, K.A. \& Xia, Z.T. (2000). A complete polarization model of a solid oxide fuel cell and its sensitivity to the change of cell component thickness, J. Power Sourc. 93, 130-140. DOI: 1016/S0378-7753(00)00556-5.

16. Akkaya, A.V. (2006). Electrochemical model for performance analysis of a tubular SOFC, International J. Energy Res., 31, 79-98. DOI: 10.1002/er.1238,

17. Kakac, S., Pramuanjaroenkij, A. \& Zhou, X.Y. (2007). A review of numerical modeling of Solid Oxide Fuel Cells, International J. Hydrog. Energ. 32, 761-786. DOI: 10.1016/j. ijhydene.2006.11.028.

18. Bachman, J., Posdziech, O., Pianko-Oprych, P., Kaisalo, N. \& Pennanen, J. (2017). Development and testing of innovative SOFC system prototype with staged stack connection for efficient stationary power and heat generation, ECS Transactions, 78, 1, 133-144. DOI: 10.11490/07801.0133ecst. 